\title{
ANALISIS STARTING MOTOR INDUKSI TIGA PHASA MENGGUNAKAN PROGRAMMABLE LOGIC CONTROLLER (PLC)
}

\author{
Sandhy Nuari ${ }^{1}$, Atmam $^{2}$, Elvira Zondra ${ }^{3}$ \\ Program Studi Teknik Elektro, Fakultas Teknik, Universitas Lancang Kuning \\ Jl. Yos Sudarso Km. 8 Rumbai, Pekanbaru, Telp. (0761) 52324 \\ Email : sandhy.nuari93@gmail.com, atmam@unilak.ac.id, elviraz@unilak.ac.id
}

\begin{abstract}
ABSTRAK
Motor induksi adalah alat listrik yang mengubah energi listrik menjadi energi mekanik. Motor induksi mempunyai banyak keunggulan dari segi teknis maupun ekonomis, karena itu motor induksi terutama jenis motor induksi tiga phasa banyak digunakan pada dunia industri. Akan tetapi motor induksi juga mempunyai kekurangan, antara lain arus starting besar yang dapat mengakibatkan penurunan tegangan sistem dan mengganggu kerja sistem peralatan lain dalam satu saluran. Pada motor induksi diperlukan suatu metode starting, yang bertujuan untuk mengurangi arus starting yang besar. Metode starting yang digunakan pada penelitian ini yaitu metode starting direct on line (DOL), star-delta, dan autotransformer, yang salah satunya dapat dioperasikan secara otomatis dengan menggunakan Programmable Logic Controller (PLC). Dari hasil penelitian diperoleh nilai arus starting motor induksi tiga phasa 10 Horse Power (HP) dengan metode starting direct on line (DOL) hubungan star sebesar 50,531 Amper, metode starting star-delta sebesar 29,301 Amper, metode starting autotransformer hubungan star 50\% sebesar 12,792 Amper, 65\% sebesar 21,618 Amper, 80\% sebesar 32,747 Amper, dan diperoleh nilai torsi starting direct on line (DOL) hubungan star sebesar 49,479 N.m, starting star-delta sebesar 16,637 N.m, starting autotransformer hubungan star $50 \%$ sebesar 12,684 N.m, $65 \%$ sebesar 21,436 N.m dan 80\% sebesar 32,471 N.m.
\end{abstract}

Kata kunci : Motor Induksi Tiga Phasa, Metode Starting, Programmable Logic Controller (PLC).

\section{ABSTRACT}

An induction motor is an electrical device which can transform electrical energy into mechanical energy. Due to advantages that they provide in terms of technical and economic, induction motors, especially three-phase induction motors are widely used in industries. However, induction motors have several disadvatages, such as huge starting current causing voltage drop in a system that will interfere other parts in the system of one particular channel. Induction motors need a starting method, aiming to reduce huge starting current. The starting methods used in this research are direct on line (DOL), star-delta, and autotransformer, one of which can be operated automatically using Programmable Logic Controller (PLC). The result shows that the value of the starting current of a 10 Horse Power (HP) three-phase induction motor using DOL method is 50.53 Amps, while using star-delta method is 29.31 Amps, and using autotransformer method of star connection of $50 \%, 65 \%$ and $80 \%$ are $12.79 \mathrm{Amps}, 21.61 \mathrm{Amps}$ and $32.74 \mathrm{Amps}$ respectively. In addition, the torsion value of DOL method of star connection is 49,479 N.m. star-delta method is $16.63 \mathrm{N.m}$, and autotransformer method of star connection of $50 \%, 65 \%$ and $80 \%$ are $12.68 \mathrm{N.m}, 21.43 \mathrm{~N} . \mathrm{m}$ and $32.47 \mathrm{~N} . \mathrm{m}$ respectively.

Keywords : Three-phase Induction Motor, Starting Methods, Programmable Logic Controller (PLC).

\section{PENDAHULUAN}

Pada masa sekarang ini motor induksi merupakan salah satu mesin listrik yang paling banyak digunakan dalam kehidupan sehari-hari, dikarenakan motor induksi lebih efisien dibandingkan mesin listrik lainnya, baik yang diaplikasikan untuk kebutuhan rumah tangga maupun industri. Motor induksi ini memiliki berbagai macam keunggulan dibandingkan mesin listrik lainnya antara lain harga dan perawatannya relatif murah, konstruksinya yang kuat dan sederhana, startingnya 
mudah serta karakteristik kerjanya yang baik, oleh karena itu motor induksi lebih banyak digunakan.

Karena banyak dan luasnya penggunaan motor induksi ini di berbagai bidang dan kebutuhan yang beragam maka dilakukan berbagai penelitian mengenai unjuk kerja motor induksi. Diantara berbagai macam penelitian yang dilakukan, terdapat salah satu permasalahan pada motor induksi yang cukup menarik dan penting untuk diteliti yakni besarnya arus starting dan torsi starting motor induksi.

Besaran arus starting dan torsi starting pada motor induksi dapat dibandingkan satu persatu dengan menggunakan beberapa jenis metode starting seperti direct on line (DOL), star-delta, dan autotransformer. Perbandingan besaran tersebut akan menghasilkan suatu karakteristik dengan tujuan untuk mengetahui cara dan waktu pengasutan motor yang paling bagus.

Pengoperasian metode starting motor induksi salah satunya dapat dioperasikan dengan menggunakan Programmable Logic Controller (PLC). PLC merupakan alat yang berfungsi untuk mengontrol rangkaian metode starting motor induksi secara otomatis.

\section{METODE PENELITIAN}

\section{Pembuatan Blok Diagram}

Diagram blok Pengoperasian motor induksi tiga phasa menggunakan metode starting direct on line (DOL), starting star-delta dan starting autotransformer dikontrol dengan programmable logic controller (PLC) tipe CPIE seperti pada Gambar 1:

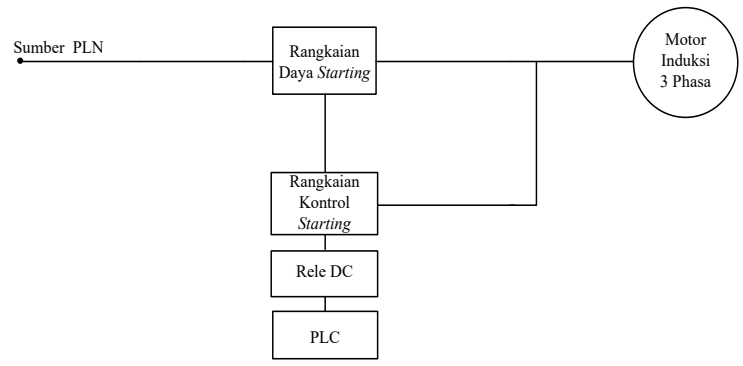

Gambar 1. Diagram Blok Motor InduksiTiga Phasa Suplai Tegangan Satu Phasa

\section{Perancangan Rangkaian Pengawatan}

Rangkaian kontrol pada starting direct on line (DOL), starting star-delta seperti pada Gambar 2, dan starting autotransformer seperti pada Gambar 3 :

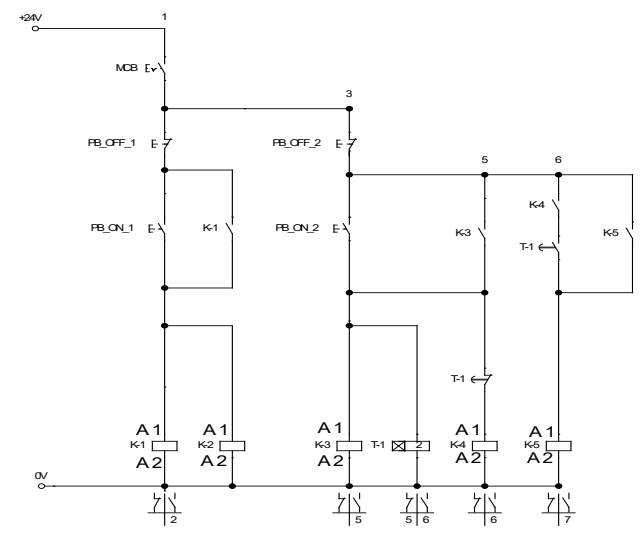

Gambar 2. Rangkaian Kontrol Starting Direct On Line (DOL) dan Starting Star-Delta

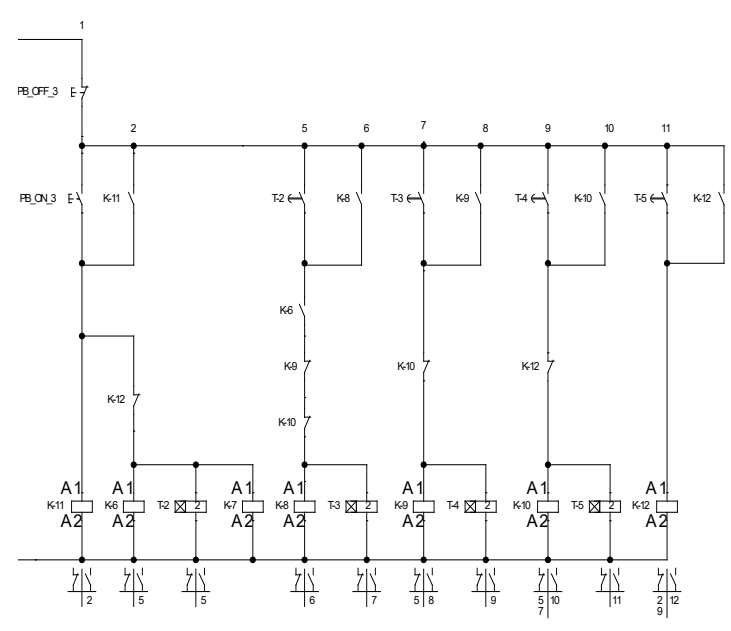

Gambar 3. Rangkaian Kontrol Starting Autotransformer

Pengawatan Rangkaian Daya Starting Motor Induksi Tiga Phasa seperti pada Gambar 4 :

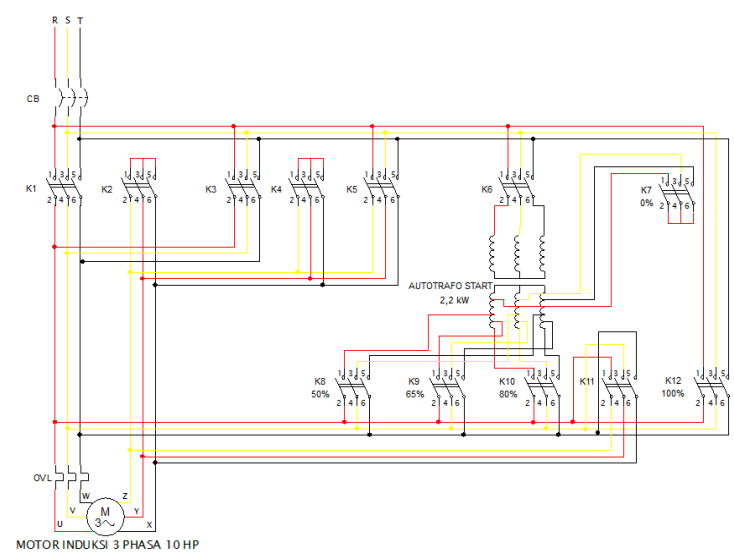

Gambar 4. Pengawatan Rangkaian Daya Starting Motor Induksi Tiga Phasa yang Terdiri dari Starting Direct On Line (DOL), Star-Delta dan Autotransformer 


\section{Membuat Program PLC}

Bahasa program yang digunakan adalah Ladder Diagram (LD). Pertama adalah konfigurasi tipe $P L C$ ditunjukan pada Gambar 5 :

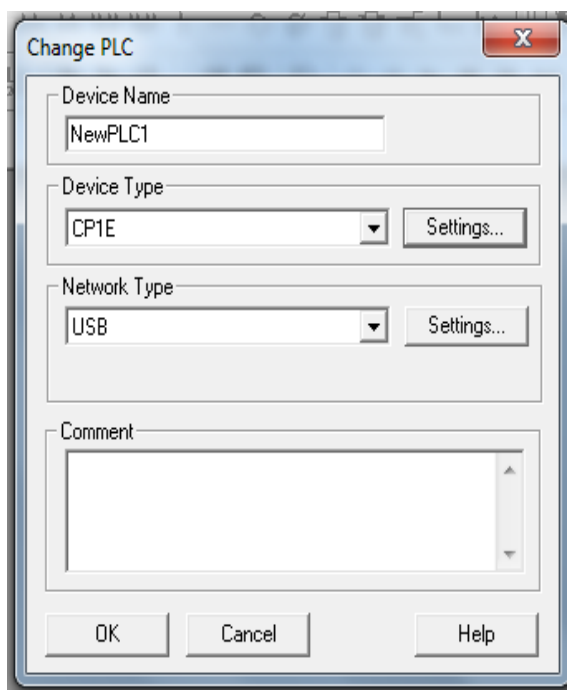

Gambar 5. Konfigurasi PLC Omron Type CPIE

Kedua setting type $C P U$ yang merupakan bagian utama dari PLC sebagai Central Proccessor Unit terhadap sinyal data input seperti pada Gambar 6 :

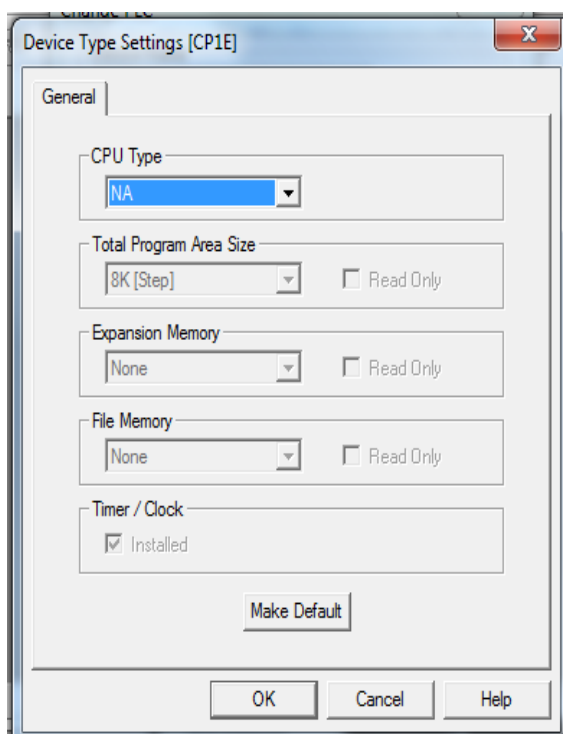

Gambar 6. Setting Type CPU
Ladder Diagram (LD) Starting Direct On Line (DOL)

Rancangan Ladder Diagram (LD) starting direct on line (DOL) seperti pada Gambar 7 :

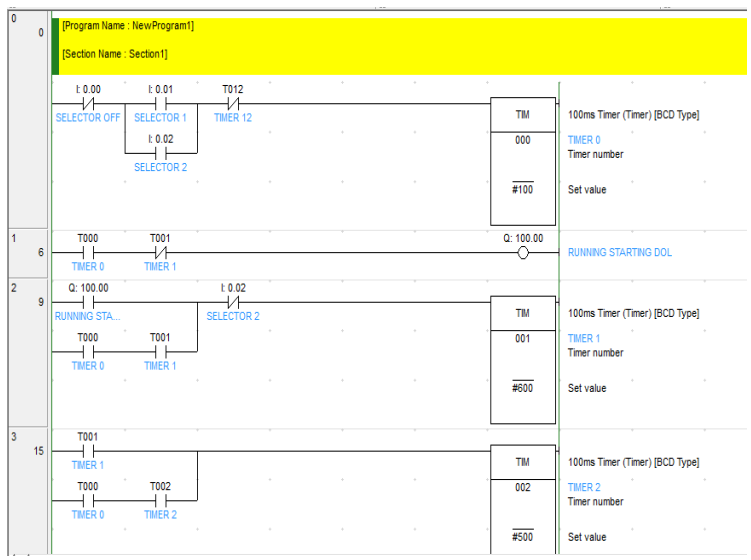

Gambar 7. Rancangan Ladder Diagram (LD) Metode Starting Direct On Line (DOL)

\section{Ladder Diagram (LD) Starting Star-Delta}

Rancangan Ladder Diagram (LD) starting stardelta seperti pada Gambar 8 :

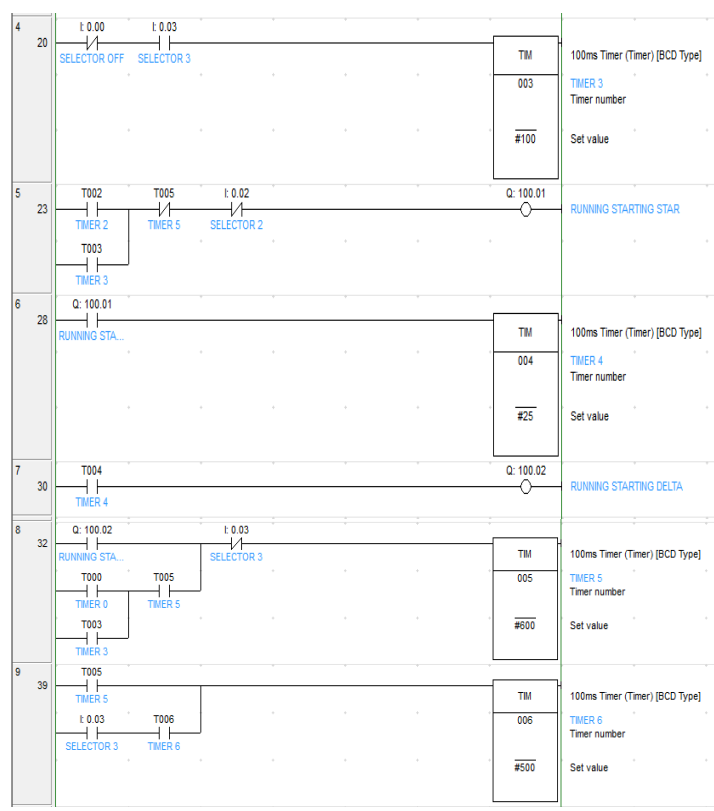

Gambar 8. Rancangan Ladder Diagram (LD) Metode Starting Star-Delta 


\section{Ladder Diagram (LD) Starting Autotransformer}

Rancangan Ladder Diagram (LD) starting autotransformer seperti pada Gambar 9 :

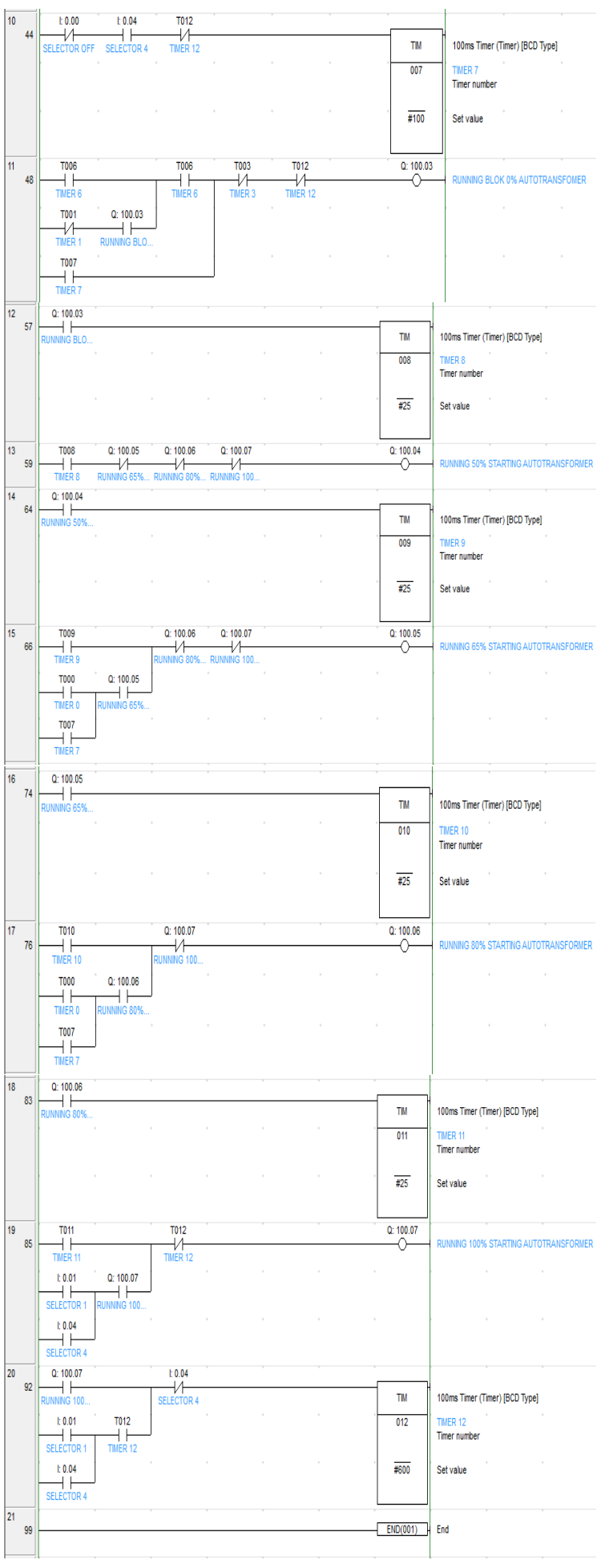

Gambar 9. Rancangan Ladder Diagram (LD) Metode Starting Autotransformer

\section{Motor Induksi}

Motor induksi bekerja berdasarkan induksi elektromagnetik dari kumparan stator kepada kumparan rotornya. Garis-garis gaya fluks yang di induksikan dari kumparan stator akan memotong kumparan rotornya sehingga timbul gaya gerak listrik (ggl) atau tegangan induksi dan karena penghantar (kumparan) rotor merupakan rangkaian yang tertutup, maka akan mengalir arus pada kumparan rotor. Penghantar (kumparan) rotor yang dialiri arus ini berada dalam garis gaya fluks yang berasal dari kumparan stator sehingga kumparan rotor akan mengalami gaya lorentz yang menimbulkan torsi yang cenderung menggerakkan rotor sesuai dengan arah pergerakan medan induksi stator. Pada rangka stator terdapat kumparan stator yang ditempatkan pada slot-slotnya yang dililitkan pada sejumlah kutup tertentu. Jumlah kutup ini menentukan kecepatan berputarnya medan stator yang terjadi yang diinduksikan ke rotornya. Makin besar jumlah kutup akan mengakibatkan makin kecilnya kecepatan putar medan stator dan sebaliknya, kecepatan berputarnya medan putar ini disebut kecepatan sinkron [1].

Ditinjau dari jumlah phasa tegangan yang digunakan maka motor induksi dapat dibedakan menjadi 2 jenis yaitu [2] :

a. Motor induksi satu phasa

Disebut motor satu phasa karena untuk menghasilkan tenaga mekanik, pada motor tersebut disuplai dengan tegangan satu phasa. Motor satu phasa tersebut disebut motor phasa belah. Macam-macam motor satu phasa yaitu motor kapasitor, motor kutub bayangan, motor repulsi, dan motor seri.

b. Motor induksi tiga phasa

Disebut motor tiga phasa karena untuk menghasilkan tenaga mekanik, pada motor tersebut disuplai dengan tegangan tiga phasa. Jenis-jenis motor ditinjau dari jenis rotor yang digunakan, yaitu motor dengan rotor lilit, motor dengan rangkai sangkar tupai, dan motor kolektor.

\section{Prinsip Kerja Motor Induksi Tiga Phasa}

Motor induksi adalah peralatan listrik yang mengubah energi listrik ke bentuk energi mekanik. Dalam motor induksi, tidak ada hubungan listrik ke rotor, arus rotor merupakan arus induksi. Arus ini berada dalam medan magnetik sehingga akan terjadi gaya pada rotor yang akan menggerakkan rotor dalam arah tegak lurus medan.

Apabila terminal stator motor induksi tiga phasa dihubungkan dengan sumber tegangan tiga phasa, maka pada kumparan stator mengalir arus tiga phasa. Arus pada tiap phasa mengahasilkan fluksi bolakbalik yang berubah-ubah. Amplitudo fluksi yang dihasilkan berubah secara sinusoidal dan arahnya tegak lurus terhadap belitan phasa [3]. 


\section{Rangkaian Ekivalen Motor Induksi Tiga Phasa}

Prinsip kerja motor induksi sama dengan prinsip kerja transformator, yaitu berdasarkan prinsip induksi elektromagnetik. Oleh karena itu motor induksi dapat dianggap sebagai transformator dengan kumparan sekunder yang berputar. Dengan demikian rangkaian ekivalen motor induksi seperti pada Gambar 1 [4]:

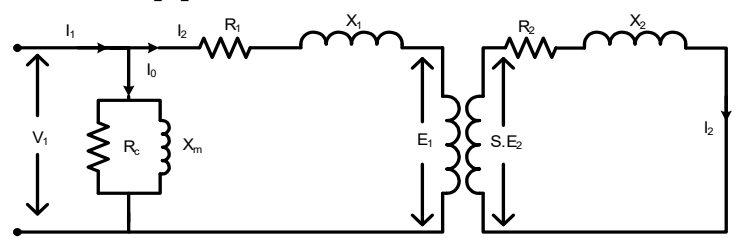

Gambar 1. Rangkaian Ekivalen Motor Asinkron

Bila rangkaian sekunder dibagi tahanannya dengan slip dan dinyatakan dalam rangkaian primer, maka rangkaian ganti dari motor induksi seperti Gambar 2 [5] :

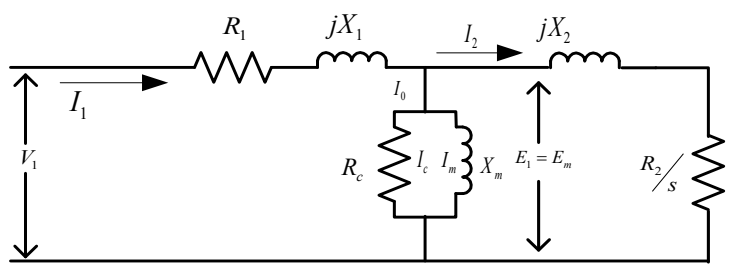

Gambar 2. Rangkaian Ekivalen dilihat dari Sisi Stator Motor Induksi

Rangkaian pengganti pada rotor motor induksi seperti pada Gambar 3 [5] :

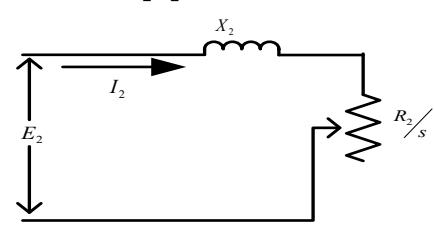

Gambar 3. Rangkaian Ekivalen Rotor

\section{Percobaan DC}

Harga $\mathrm{R}_{1 \mathrm{DC}}$ dapat dihitung, untuk kumparan dengan hubungan star, adalah sebagai berikut [6] :

$$
\begin{aligned}
& R_{1 D C}=\frac{V_{D C}}{2 I_{D C}} \\
& R_{1}=k \times R_{1 D C}
\end{aligned}
$$

Ketarangan :

$$
\mathrm{k}=\text { Faktor pengali, besarnya 1,1-1,3 [5] }
$$

\section{Percobaan Rotor Beban Nol}

Dengan tidak adanya beban mekanis yang terhubung ke rotor dan tegangan normal diberikan ke terminal, maka didapat besar sudut phasa antara arus $\left(\mathrm{I}_{0}\right)$ dan tegangan $\left(\mathrm{V}_{0}\right)$ adalah $[5]$ :

$$
\theta_{0}=\cos ^{-1}\left(\frac{P_{0}}{V_{0} I_{0}}\right)
$$

Keterangan :

$\mathrm{P}_{0} \quad=\mathrm{P}_{\mathrm{nl}} \quad=$ Daya saat beban nol per phasa

$\mathrm{V}_{0} \quad=\mathrm{V}_{\mathrm{nl}}=$ Tegangan masukan saat beban nol

$\mathrm{I}_{0} \quad=\mathrm{I}_{\mathrm{nl}} \quad=$ Arus beban nol

Kemudian reaktansi beban nol didapat [5] :

$$
X_{n l}=X_{1}+X_{m}
$$

Dalam keadaan yang sebenarnya $R_{1}$ lebih kecil jika dibandingkan dengan $X_{m}$ dan juga $R_{c}$ jauh lebih besar dari $\mathrm{X}_{\mathrm{m}}$, sehingga impedansi yang didapat dari percobaan beban nol dianggap $j X_{I}$ dan $j X_{m}$ yang diserikan [5].

$$
Z_{n l}=\frac{V_{n l}}{I_{n l} \sqrt{3}}
$$

Sehingga didapat [5] :

$$
R_{n l}=\frac{P_{n l}}{I_{n l}^{2}}
$$

Maka reaktansi beban nol [5] :

$$
X_{n l}=\sqrt{Z_{n l}^{2}-R_{n l}^{2}}
$$

Keterangan :

$\mathrm{X}_{\mathrm{nl}}=$ Reaktansi rotor beban nol

$\mathrm{R}_{\mathrm{nl}}=$ Resistansi rotor beban nol

$\mathrm{Z}_{\mathrm{nl}}=$ Impedansi rotor beban nol

$\mathrm{X}_{1}=$ Impedansi stator

$\mathrm{X}_{\mathrm{m}}=$ Reaktansi magnetisasi

\section{Percobaan Rotor Tertahan}

Impedansi perphasa pada saat rotor tertahan $\left(\mathrm{Z}_{\mathrm{LR}}\right)$ dapat dirumuskan sebagai berikut [5] :

$$
Z_{L R}=\frac{V_{L R}}{\sqrt{3 . I_{L R}}}
$$

Resistansi stator pada saat rotor ditahan [5] :

$$
R_{L R}=\frac{P_{L R}}{I_{L R}^{2}}
$$


Atau [1] :

$$
R_{L R}=R_{1}+R_{2}
$$

Maka reaktansi rotor tertahan [5] :

$$
X_{L R}=\left|Z_{L R}\right| \sin \theta
$$

Keterangan :

$\mathrm{V}_{\mathrm{LR}} \quad$ = Tegangan rotor tertahan

$\mathrm{P}_{\mathrm{LR}} \quad=$ Daya rotor tertahan

$\mathrm{I}_{\mathrm{LR}}=$ Arus rotor tertahan

$\mathrm{R}_{1} \quad=$ Resistansi stator perphasa

$\mathrm{R}_{2} \quad=$ Resistansi rotor perphasa

\section{Rangkaian Thevenin Motor Induksi Tiga Phasa}

Karakteristik torka terhadap slip diperoleh dengan membuat rangkaian Thevenin pada Gambar 4 [6] :

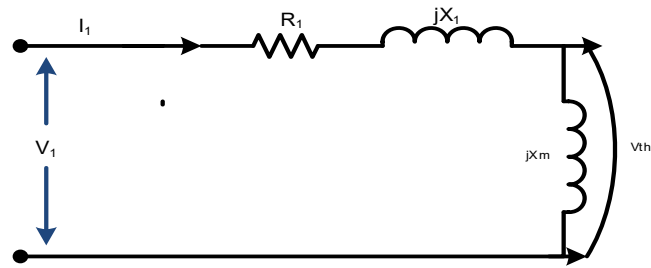

Gambar 4. Rangkaian Thevenin Motor Induksi

Resistansi Thevenin diperoleh [6] :

$$
\mathrm{R}_{\mathrm{Th}}=\mathrm{R}_{1}\left(\frac{\mathrm{X}_{\mathrm{m}}}{\mathrm{X}_{1}+X_{m}}\right)^{2}
$$

Tegangan Thevenin diperoleh [6] :

$$
\mathrm{V}_{\mathrm{Th}}=\mathrm{V}_{\phi} \times \frac{X_{m}}{\sqrt{R_{1}^{2}+\left(X_{1}+X_{m}\right)^{2}}}
$$

Tegangan per phasa [6] :

$$
V_{\phi}=\frac{V_{s}}{\sqrt{3}}
$$

Sedangkan Reaktansi Thevenin $\mathrm{X}_{\mathrm{Th}} \approx \mathrm{X}_{1}$.

Untuk menghitung arus starting motor induksi tiga phasa dapat digunakan persamaan berikut [6] :

$$
\left[I_{\text {start }}\right]=\frac{V_{T h}}{\sqrt{\left(R_{T h}+R_{2}\right)^{2}+\left(X_{T h}+X_{2}\right)^{2}}}
$$

Dan untuk menghitung torsi starting motor induksi tiga phasa dapat digunakan persamaan berikut [6] :

$$
\left[T_{\text {start }}\right]=\frac{3 \cdot\left(V_{T h}\right)^{2} \cdot\left(R_{2} / s\right)}{\omega_{s} \cdot\left(R_{T h}+R_{2} / s\right)^{2}+\left(X_{T h}+X_{2}\right)^{2}}
$$

Keterangan :

$\mathrm{V}_{\phi} \quad=$ Tegangan per phasa

$\mathrm{R}_{1} \quad=$ Tahanan stator

$\mathrm{R}_{2} \quad=$ Tahanan rotor

$\mathrm{X}_{1} \quad=$ Impedansi stator

$\mathrm{X}_{2} \quad=$ Impedansi rotor

$\mathrm{X}_{\mathrm{m}} \quad=$ Reaktansi magnetisasi

$s \quad=$ Slip

\section{HASIL DAN PEMBAHASAN}

Arus dan Torsi Starting Direct On Line (DOL) Hubungan Kumparan Motor Star

Untuk mendapatkan arus starting direct on line (DOL) hubungan kumparan motor star digunakan persamaan (16) dan untuk mendapatkan torsi starting direct on line (DOL) hubungan kumparan motor star digunakan persamaan (17) sebagai berikut :

$$
\begin{aligned}
I_{\text {start }} & =\frac{377,821}{\sqrt{(1,61+1,711)^{2}+(3,349+3,349)^{2}}} \\
& =50,531 \text { Amper }
\end{aligned}
$$

$$
T_{\text {start }}=\frac{3 \times(377,821)^{2} \times(1,711 / 0,033)}{157 \times(1,61+1,711 / 0,033)^{2}+(3,349+3,349)^{2}}
$$$$
=49,479 \mathrm{~N} \cdot \mathrm{m}
$$

\section{Arus dan Torsi Starting Star-Delta}

Untuk mendapatkan arus starting star-delta digunakan persamaan (16) dan untuk mendapatkan torsi starting star-delta digunakan persamaan (17) sebagai berikut :

$$
\begin{aligned}
I_{\text {start }} & =\frac{219,083}{\sqrt{(1,61+1,711)^{2}+(3,349+3,349)^{2}}} \\
& =29,301 \text { Amper }
\end{aligned}
$$

$$
\begin{aligned}
T_{\text {start }} & =\frac{3 \times(219,083)^{2} \times(1,711 / 0,033)}{157 \times(1,61+1,711 / 0,033)^{2}+(3,349+3,349)^{2}} \\
& =16,637 \mathrm{~N} . \mathrm{m}
\end{aligned}
$$




\section{Arus dan Torsi Starting Autotransformer Hubungan Kumparan Motor Star}

Untuk mendapatkan arus starting autotransformer hubungan kumparan motor star digunakan persamaan (16) dan untuk mendapatkan torsi autotransformer hubungan kumparan motor star digunakan persamaan (17), yang dikalikan dengan bersarnya masing-masing tapping autotransformer $50 \%, 65 \%$, dan $80 \%$ sebagai berikut :

$$
\begin{aligned}
I_{\text {start }} & =(50 \%)^{2} \times \frac{382,589}{\sqrt{(1,61+1,711)^{2}+(3,349+3,349)^{2}}} \\
& =12,792 \text { Amper }
\end{aligned}
$$

$$
\begin{aligned}
T_{\text {start }} & =(50 \%)^{2} \times \frac{3 \times(382,589)^{2} \times(51,848)}{157 \times(1,61+51,848)^{2}+(3,349+3,349)^{2}} \\
& =12,684 \mathrm{~N} . \mathrm{m}
\end{aligned}
$$

Hasil perhitungan arus starting, dan torsi starting motor induksi tiga phasa menggunakan metode starting direct on line (DOL) hubungan kumparan motor star, starting direct on line (DOL) hubungan kumparan motor delta, starting star-delta, starting autotransformer $50 \%, 65 \%$, dan $80 \%$ hubungan hubungan kumparan motor star, dan

\begin{tabular}{|c|c|c|c|c|}
\hline \multirow{2}{*}{$\begin{array}{l}\text { Metode Starting } \\
\text { dan Hubungan } \\
\text { Kumparan Motor }\end{array}$} & \multicolumn{2}{|c|}{ Hasil Perhitungan } & \multicolumn{2}{|c|}{ Hasil Pengukuran } \\
\hline & $\begin{array}{c}I_{\text {Start }} \\
\text { (Amper) }\end{array}$ & $\begin{array}{l}T_{\text {Start }} \\
(N . m)\end{array}$ & $\begin{array}{c}\text { IStart }_{\text {(Inrush) }} \\
\text { (Amper) }\end{array}$ & $\begin{array}{c}\text { IStart }_{\text {(Peak) }} \\
\text { (Amper) }\end{array}$ \\
\hline DOL Hubungan Star & 50,531 & 49,479 & 34,31 & 61 \\
\hline DOL Hubungan Delta & 86,918 & 146,398 & 50,9 & 79 \\
\hline Star-Delta & 29,301 & 16,637 & 11,1 & 47 \\
\hline $\begin{array}{c}\text { Autotransformer } 50 \% \\
\text { Hubungan Star }\end{array}$ & 12,792 & 12,684 & 14,8 & 23 \\
\hline $\begin{array}{c}\text { Autotransformer } 65 \% \\
\text { Hubungan Star }\end{array}$ & 21,618 & 21,435 & 11,6 & 18 \\
\hline $\begin{array}{c}\text { Autotransformer } 80 \% \\
\text { Hubungan Star }\end{array}$ & 32,747 & 32,471 & 7,7 & 12 \\
\hline $\begin{array}{c}\text { Autotransformer } 50 \% \\
\text { Hubungan Delta }\end{array}$ & 22,179 & 38,129 & 21,3 & 34 \\
\hline $\begin{array}{c}\text { Autotransformer } 65 \% \\
\text { Hubungan Delta }\end{array}$ & 37,483 & 64,439 & 2,7 & 12 \\
\hline $\begin{array}{c}\text { Autotransformer } 80 \% \\
\text { Hubungan Delta }\end{array}$ & 56,778 & 97,613 & 3,4 & 11 \\
\hline
\end{tabular}
autotransformer $50 \%, 65 \%$, dan $80 \%$ hubungan kumparan motor delta seperti pada Tabel 1 :

Tabel 1. Hasil Perhitungan dan Pengukuran Arus Starting dan Torsi Starting Motor Induksi Tiga Phasa

\section{KESIMPULAN}

Berdasarkan hasil perhitungan yang dilakukan, maka dapat dibuat beberapa kesimpulan sebagai berikut :

1. Dari hasil perhitungan diperoleh nilai arus starting motor induksi tiga phasa 10 Horse Power (HP) dengan metode starting Direct On Line (DOL) hubungan star sebesar 50,531 Amper, Direct On Line (DOL) hubungan delta sebesar 86,918 Amper, metode starting StarDelta sebesar 29,301 Amper, metode starting Autotransformer hubungan star 50\% sebesar 12,792 Amper, 65\% sebesar 21,618 Amper, 80\% sebesar 32,747 Amper, dan metode starting Autotransformer hubungan delta 50\% sebesar 22,179 Amper, 65\% sebesar 37,483 Amper, 80\% sebesar 56,778 Amper.
2. Dari hasil perhitungan diperoleh nilai torsi starting motor induksi tiga phasa $10 \mathrm{HP}$ dengan metode starting DOL hubungan star sebesar 49,479 N.m, DOL hubungan delta sebesar 146,398 N.m, metode starting Star-Delta sebesar 16,637 N.m, metode starting Autotransformer hubungan star 50\% sebesar 12,684 N.m, $65 \%$ sebesar 21,436 N.m, $80 \%$ sebesar 32,471 N.m, dan metode starting Autotransformer hubungan delta 50\% sebesar 38,129 N.m, $65 \%$ sebesar 64,439 N.m, $80 \%$ sebesar 97,613 N.m.

3. Dari metode starting Direct On Line (DOL), starting Star-Delta, dan starting Autotransformer diketahui arus dan torsi starting dengan metode starting Direct On Line (DOL) yang menghasilkan arus dan torsi start paling besar dibandingkan arus dan torsi start dengan metode starting Star-Delta dan metoda starting Autotransformer. 


\section{DAFTAR PUSTAKA}

[1] Anton, 2013, Unjuk Kerja Dan Pemanfaatan Inverter Sebagai Pengendali Kecepatan Motor Induksi 3 Phasa, Jurnal Elektron, ISSN $2085-$ 6989, Vol. 5, No. 2, Padang.

[2] Sumanto, 1989, Mesin Arus Searah, Andi Offset, Yogyakarta.

[3] Zuhal, 1991, Dasar Teknik Tenaga Listrik, ITB, Bandung.

[4] Rijono Yon, 1997. Dasar Teknik Tenaga Listrik, Andi, Yogyakarta.

[5] Bimbhra, P, S., 1979, Electrical Machinery, Khanna Publisher, Australia.

[6] Chapman, Stephen J., 2005, Electric Machinery Fundamental, Fourt Edition, McGraw-Hill Companies, Inc., New York. 